Check for updates

Cite this: RSC Adv., 2019, 9, 6779

Received 17th January 2019

Accepted 13th February 2019

DOI: 10.1039/c9ra00422j

rsc.li/rsc-advances

\title{
Synthesis of fluorescent drug molecules for competitive binding assay based on molecularly imprinted polymers $\uparrow$
}

\author{
Muyasier Wubulikasimu, ${ }^{a}$ Turghun Muhammad, (D) *a Mukhtar Imerhasan, ${ }^{\text {*a }}$ \\ Nurmemet Hudaberdi, ${ }^{b}$ Wenwu Yang, ${ }^{a}$ Jianzhang Zhao (D) c and Xiaojun Peng (D)
}

\begin{abstract}
Fluorescent immunosorbent assay (FIA) is very promising for sensitive and selective analysis in biomedical applications. Here, we proposed an assay, using fluorescent engineering of analytes and the corresponding molecularly imprinted polymers (MIPs) as a plastic antibody. Three drug molecules (metronidazole, zidovudine and lamivudine) were condensed with 9-aminoacridine, using succinic anhydride as a spacer. The target products were characterized with ${ }^{1} \mathrm{H}-\mathrm{NMR}$, IR and mass spectrometry. UV-vis absorption and fluorescent properties of the fluorophore-labeled drug molecules were investigated. Feasibility of the fluorescent biomimetic immunosorbent assay based on MIPs was demonstrated in the solution. This work will provide sound foundation for the future application in real sample.
\end{abstract}

\section{Introduction}

Fluorescence labeling with fluorescent protein or organic molecules is one of the most common methodologies used for bioanalytical purposes. ${ }^{1}$ Recently, the development and innovation of fluorescent labeling has greatly facilitated the drug analysis. Metronidazole, zidovudine, lamivudine are common and fundamental drugs which are playing important roles in treatment of several types of diseases. And safety use and research about these drugs have been attracted worldwide attention in medical and chemical communities. Metronidazole is a nitroimidazole antibiotic that was introduced in 1950s. It has been widely used for infections caused by protozoa (e.g., trichomoniasis, giardiasis, amoebiasis) and anaerobic bacteria (e.g., Clostridium spp., Bacteroides spp.). ${ }^{2}$ Nowadays metronidazole is still commonly used because of its potent activity, attractive pharmacokinetic and pharmacodynamic properties, favorable side-effect profile, and low cost. ${ }^{3}$ It has excellent bioavailability $(>90 \%)$ and penetrates cerebrospinal fluid and hepatic abscesses. Zidovudine (AZT) belongs to the class of nucleoside reverse-transcriptase inhibitors (NRTIs), ${ }^{4}$ and it is a pyrimidine synthetic analogue active against human

${ }^{a}$ College of Chemistry \& Chemical Engineering, Xinjiang University, Xinjiang Key Laboratory of Oil and Gas Fine Chemicals, Urumqi 830046, P. R. China. E-mail: imerhasan@xju.edu.cn; turghunm@sina.com

${ }^{b}$ Yili Chuanning Biotechnology Co., Ltd., Yining 835000, P. R. China

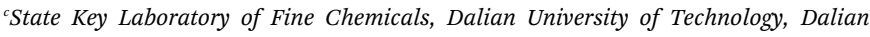
116024, P. R. China

$\dagger$ Electronic supplementary information (ESI) available. See DOI: $10.1039 / \mathrm{c} 9 \mathrm{ra} 00422 \mathrm{j}$ immunodeficiency virus type 1 (HIV-1). ${ }^{5}$ Zidovudine has been approved for the treatment of HIV-1, and even helping with prevention of maternal-fetal HIV-1 transmission. ${ }^{6}$ Lamivudine is a potent and effective anti-retroviral drug, which is prescribed in the human immune virus (HIV) therapy. It is a water-soluble nucleoside analog and plays a vital role to inhibit reverse transcriptase. ${ }^{7}$

Currently, these drugs are often determined and analysed by HPLC and HPLC-MS. However, their fluorescence analysis is rarely reported in relevant field. Herein, it is important to develop a fluorescent biomimetic immunosorbent assay which is simple, selective and accurate.

Fluorescence reagents play an extremely important role and have always been the focus of research in the field of chemistry and biological analysis. ${ }^{8}$ Among them, 9-aminoacridine (9-AA) is the parent compound of a family of pharmacologically active model substances ${ }^{9}$ and is also a fluorescent dye of nitrogen heterocyclic bases. 9-AA has the active amino group which can be used to label other molecules. The molecules containing 9-AA moiety have been shown to have high biological activity such as antibacterial, mutagenic and antitumor effect. ${ }^{10,11}$ Owing to good fluorescence, physicochemical properties, biological activities, and as well as carrying with active amino group, 9-AA has been widely utilized in different areas such as pharmacology, toxicology, organic synthesis, and biochemistry. ${ }^{12,13}$ However, utilization this molecule for fluorescence labelling and further use in immune assay is not found in literature reports.

Now, labelling of proteins and drug molecules have been carried out using click-chemistry, condensation reaction, ester/ amide bond formation, and thiol-ene reactions. ${ }^{14}$ It is wellknown that the labelling reagent shouldn't bring obvious 
change about the properties of analyte such as chemical and biological activities. To address this issue, a spacer is often used to connect the target molecule with a fluorescence reagent. Carrying with reactive groups, the spacer can facilitate labelling reactions. As a spacer, succinic anhydride (SA) is often used to connect amines or alcohols by ester or amide bond. ${ }^{15,16} \mathrm{SA}$ produces a four-carbon chain between the two molecules through two step reactions. ${ }^{17-19} \mathrm{SA}$ is a good choice in the labelling of drug molecules.

It has been proved on many occasions that molecularly imprinted polymers (MIPs) have the potential to become costefficient and robust alternatives to natural antibodies as a recognition element in bioanalytical assays. ${ }^{20}$ MIPs, as a biomimetic synthetic receptor, have been widely used in all respects, due to specific recognition, high specificity, simple preparation, low cost and high temperature tolerance. ${ }^{\mathbf{2 1 , 2 2}}$ Hence, MIPs were also commonly used in immunoassay. ${ }^{23,24}$ The immune adsorption experiment is simple and fast, meanwhile, fluorescence properties can improve the sensitivity of drug analysis.

In this study, we selected 9-AA as a fluorescent reagent and succinic anhydride as a spacer to label drug molecules (metronidazole, zidovudine and lamivudine) in Scheme 1 . The synthesized molecules (MNZ-F, AZT-F, 3TC-F) were further characterized and verified. Finally, the labeled drug molecules were used as competitors, to develop competitive binding assay for the three drugs using corresponding MIPs (plastic antibodies).

\section{Results and discussion}

\subsection{Preparation}

Structures of target compounds are depicted in Scheme 1(A). The target compounds MNZ-F, AZT-F, 3TC-F were obtained by conjugation of drug molecules with fluorescent labeling reagent 9-AA via spacer succinic anhydride. Synthetic routes of drug-linker-fluorophore was shown in Scheme 1(B). Nucleophilic addition reaction between the active group of succinic anhydrides and $-\mathrm{OH}$ or $-\mathrm{NH}_{2}$ group of drug molecules (MNZ, AZT, 3TC-ES) gives the intermediate (D-SA). Then, the intermediate was used as a building block for the synthesis of the target compounds. $\mathrm{N}$-Hydroxysuccinimide was used to produce activated intermediates (D-SA-HAS). Then the intermediate was further labeled with 9-AA by nucleophilic substitution to yield the target compounds. Molecular structures of MNZ-F, AZT-F and 3TC-F were confirmed with ${ }^{1} \mathrm{H}$ NMR, IR and MS spectra. The yields of MNZ-F, AZT-F and 3TCF were $29 \%, 27 \%$ and $14 \%$, respectively. Conjugating surface and steric hindrance of 3TC-F are larger than that of MNZ-F,

A<smiles></smiles>

MNZ-F<smiles>Cc1cn([C@H]2C[C@H](N)[C@@H](COC(=O)CCC(=O)Nc3c4ccccc4nc4ccccc34)O2)c(=O)[nH]c1=O</smiles><smiles>CCCCCCOC(C)=O</smiles>

3TC-F

B

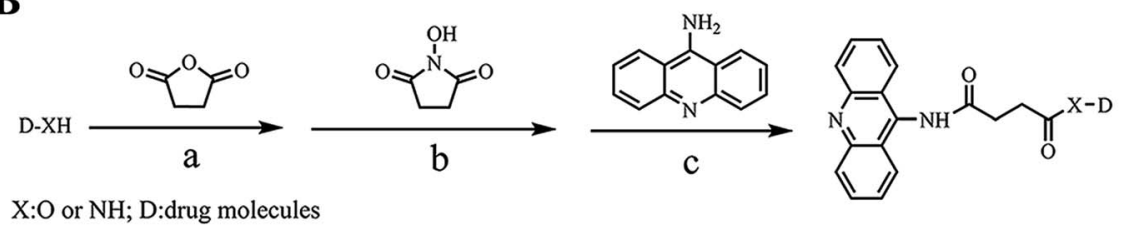

Scheme 1 (A) Fluorescent labelled drug molecules, MNZ-F, AZT-F and 3TC-F; (B) synthetic route of the fluorescence labelling process (a) pyridine or anhydrous acetone, rt, stir $24 \mathrm{~h}$; (b) anhydrous acetone or anhydrous dimethylformamide (DMF), dimethylaminopyridine (DMAP), N,Ndicyclohexylcarbodiimide (DCC), rt, stir 36 h; (c) anhydrous DMF, DMAP, rt, stir 36 h. 

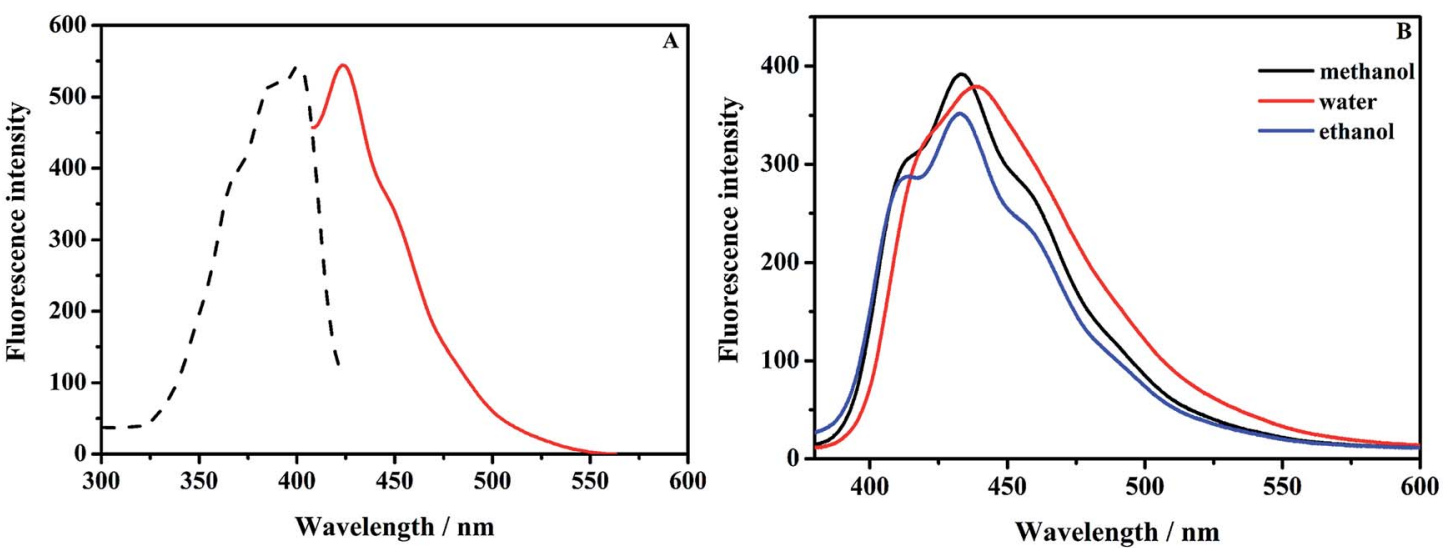

Fig. 1 (A) Fluorescence excitation (EX) and emission (EM) spectra of MNZ-F in methanol solution; (B) fluorescence emission spectra of MNZ-F in various solvents. ( $\lambda_{\mathrm{ex}}=366 \mathrm{~nm}$, sensitivity of 2 , slit width of $10 / 10 \mathrm{~nm}$ ).

AZT-F, so yield of 3TC-F is lower than that of other two products.

\subsection{Fluorescence characteristics}

Firstly, optically matched solutions of 9-AA, MNZ-F and AZT-F were prepared. Excitation spectra (EX) and emission spectra (EM) of MNZ-F was shown in Fig. 1(A). The results showed that 9-AA has two strong peaks in the range of $300-600 \mathrm{~nm}$ in the excitation spectrum (Fig. S1A $\dagger$ ). The maximum excitation wavelengths of 9-AA in methanol are at $405 \mathrm{~nm}$ and $425 \mathrm{~nm}$, respectively. However, compared to labeling reagent, MNZ-F and AZT-F (Fig. S2A $\dagger$ ) showed only a strong peak in the range of 300-600 nm. Excitation peak position of MNZ-F and AZT-F were blue-shifted to $400 \mathrm{~nm}$ and $366 \mathrm{~nm}$. The maximum emission wavelength of 9-AA in methanol are $425 \mathrm{~nm}$ and $460 \mathrm{~nm}$, while, emission peak position of MNZ-F and AZT-F were blue-shifted to $440 \mathrm{~nm}, 430 \mathrm{~nm}$, respectively. The behavior differences in photoluminescence might be caused by the thiazole ring and pyrrolidine ring in the fluorescent labeling drugs.

Generally, the polarity of a solvent influences the emission spectra of fluorophores in quantum yields and spectral shifts. ${ }^{25}$ A fluorescent probe is usually strongly fluorescent in hydrophobic environment but weakly fluorescent in hydrophilic environment (or in more polar solvents). ${ }^{25,26}$ Interestingly, the opposite behavior was observed on MNZ-F, 9-AA and AZT-F, shown in Fig. 1(B), S1B and S2B, $\dagger$ where fluorescence emission is stronger in water than in ethanol. This phenomenon was also reported in the case of acridine pyrene-3-carboxaldehyde ${ }^{27}$ and 7-methoxy-4-methylcoumarins. ${ }^{28,29}$ Moreover, AZT-F displayed the highest fluorescence intensity in water, but 9-AA and MNZ-F showed the highest in methanol.

The results showed that the fluorescent labelled drugs have good fluorescence properties. The molecule AZT-F has higher relative fluorescence quantum yield (0.564) as compared to that of MNZ-F (0.370) and 3TC-F (0.251). Relative fluorescence quantum yield was given in Table 1. Calibration curve parameters were listed in Table 2. The data showed that there was a good linear relationship between the concentration of the labeled drugs and the relative fluorescence intensity.

\subsection{Competitive binding assay}

Principle of the fluorescent competitive binding assay is shown in Scheme 2. The imprinted polymers were utilized in a competitive assay to detect MNZ and AZT. The assay principle is based on the competition of the fluorescently labeled compound and unlabeled analyte in solution for the binding

Table 2 Calibration curve parameters

\begin{tabular}{lllll}
\hline $\begin{array}{l}\text { Labeled } \\
\text { drug }\end{array}$ & Regression equation & $\begin{array}{l}\text { Linear range } \\
(\mathrm{mmol})\end{array}$ & $R^{2}$ & Solvent \\
\hline MNZ-F & $y=92.62+2401.77 x$ & $0.006-0.18$ & 0.9394 & $\begin{array}{l}\text { Methane } \\
\text { chloride }\end{array}$ \\
AZT-F & $y=48.81+4400.03 x$ & $0.01-0.20$ & 0.9975 & $\begin{array}{l}\text { Acetonitrile } \\
\text { Acetonitrile }\end{array}$
\end{tabular}

Table 1 Relative fluorescence quantum yields

\begin{tabular}{lllll}
\hline Compound & Solvent & $\begin{array}{l}\text { Refractive } \\
\text { index } \eta\end{array}$ & Gradient $\left(\times 10^{-5}\right)$ & $\begin{array}{l}\text { Relative quantum } \\
\text { yield }\end{array}$ \\
\hline Quinine sulfate & $0.1 \mathrm{M} \mathrm{H}_{2} \mathrm{SO}_{4}$ & 1.333 & 6.56 & 0.547 \\
9-AA & Ethanol & 1.362 & 4.56 & 0.397 \\
MNZ-F & Water & 1.333 & 4.44 & 0.370 \\
AZT-F & Water & 1.333 & 6.76 & 0.564 \\
3TC-F & Water & 1.333 & 3.01 & 0.251
\end{tabular}




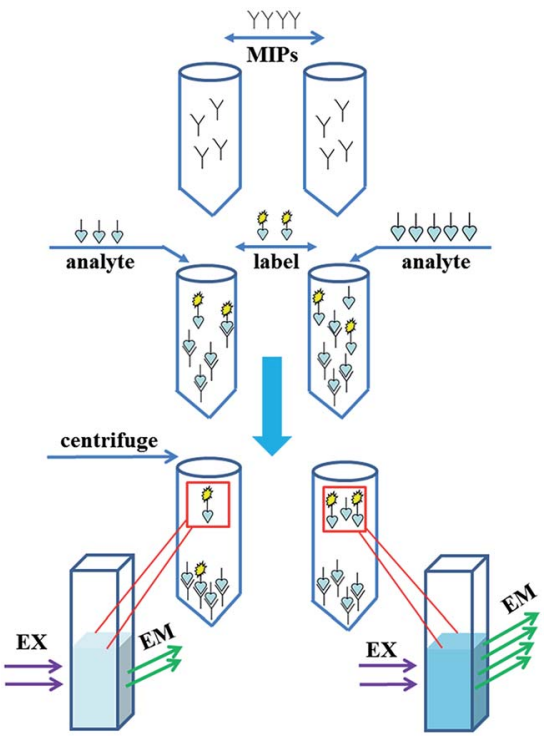

Scheme 2 Principle of the fluorescent biomimetic immunosorbent assay. MIPs: molecularly imprinted polymers (plastic antibody).

sites of the MIPs. If there is less analyte in the sample (left row of Scheme 2), the fluorescent label will have more chance to occupy the limited binding sites. In the consequence, the supernatant solution shows weaker fluorescence. Oppositely, there more analyte present in the sample (right row of Scheme 2), less label will bind with MIPs and stronger fluorescent shown in the supernatant. As labeled compound, MNZ labeled with 9-AA was used. After removing the polymers by centrifugation, supernatant was measured by fluorescence spectrophotometer.

The application of the competitive fluorescent assay was investigated with a fixed concentration of the MNZ imprinted polymer and using MNZ (0-0.36 mM) as an analyte, in the presence of $0.018 \mathrm{mM}$ MNZ-F in chloroform. The results are shown in the Fig. 2(A). MNZ competed with MNZ-F for binding to the imprinted polymers. And the MNZ imprinted polymers were reported elsewhere by our group..$^{30}$ After centrifugation, the fluorescent intensity of the solution increased with the increasing of MNZ concentration. The results of AZT competitive assay are shown in the ESI (Fig. S3 $\uparrow$ ). A good linearity $\left(R^{2}=\right.$ 0.9818) was found between fluorescence intensity and MNZ concentration, shown in Fig. 2(B). Further work needs to be done to confirm feasibility of the assay in the real sample matrix from the point of optimum amount of MIPs, concentration of the label, solvent and finding out $\mathrm{IC}_{50}$.

\section{Experimental section}

\subsection{General methods}

All of the chemicals of reagent grade quality were commercially available and used as received. 9-Aminoacridine (9-AA) was synthesized according to ref. 31. Metronidazole, zidovudine and lamivudine were purchased from Hangzhou Dayang General Co. Ltd. (Hangzhou, China). Acetic anhydride was purchased from Kaifeng Chemical Reagent Factory (Kaifeng, China). Dimethylaminopyridine, $N, N$-dicyclohexylcarbodiimide, dimethylformamide and pyridine were purchased from Sinopharm Chemical Reagent Co. Ltd. (Shanghai, China). All fluorescence spectral measurements were conducted by a fluorescence spectrophotometer (970 CRT Shanghai, China) with a tunable excitation light source. UV-vis analysis was performed a UV1800 spectrophotometer (Shimadzu, Japan). ${ }^{1} \mathrm{H}$ NMR spectra were measured using a ZAB-HS-400 NMR (Varian, America) using trimethylsilane as interior label. Fourier transform infrared spectroscopy was performed using $\mathrm{KBr}$ pellets on a EQUINOX 55 (Bruker, Germany) between 400 and $4000 \mathrm{~cm}^{-1}$. Mass spectrum were detected in EMS mode. For all experiments double distilled water was used.

\subsection{Measurement of quantum yield}

We determined the fluorescence quantum yield of the products obtained according to the reported method. ${ }^{32}$ Quinine sulfate was used as a reference standard fluorophore and using $0.1 \mathrm{M}$ $\mathrm{H}_{2} \mathrm{SO}_{4}$ as solvent, the emission and absorption spectra of all compounds were listed in Table 1 . The relative fluorescence quantum yield was calculated by eqn (1):
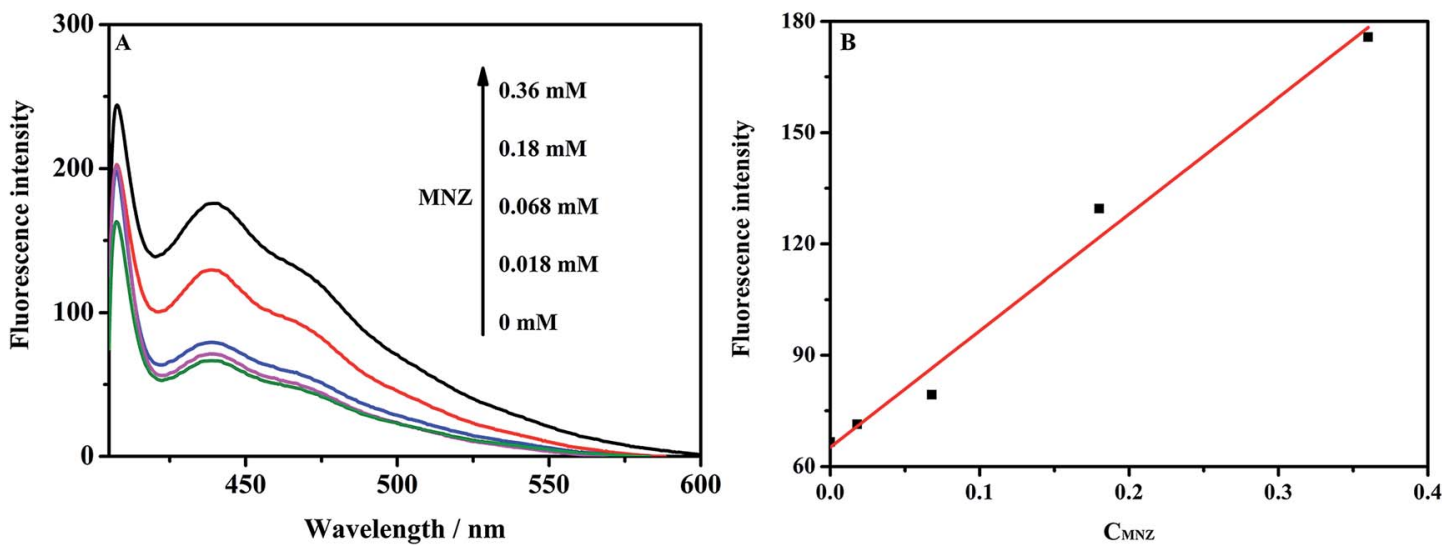

Fig. 2 (A) Fluorescence spectra of competitive binding assay of $0.018 \mathrm{mM} \mathrm{MNZ-F}$ in the presence of $0-0.36 \mathrm{mM} \mathrm{MNZ}\left(\lambda_{\text {ex }}=395 \mathrm{~nm}\right.$, sensitivity of 2, slit width of $20 / 10 \mathrm{~nm}$ ) in chloroform solution; (B) relationship between fluorescence intensity and concentration of MNZ. 


$$
\Phi_{x}=\Phi_{\mathrm{ST}}\left(\frac{\operatorname{Grad}_{x}}{\operatorname{Grad}_{\mathrm{ST}}}\right)\left(\frac{\eta_{x}}{\eta_{\mathrm{ST}}}\right)^{2}
$$

where $\Phi$ is fluorescence quantum yield, the subscript $x$ represents the sample to be tested, subscript ST denotes reference, Grad is the slope of the curve derived from the integral area of fluorescence intensity and the absorbance corresponding to different absorbance (provided in the Fig. S4 $\dagger$ ), $\eta$ is the refractive index of the solvent, the refractive index of $0.1 \mathrm{M} \mathrm{H}_{2} \mathrm{SO}_{4}$ and water is 1.333 .

\subsection{Synthesis}

3.3.1 Synthesis of compound MNZ-SA. Compound MNZ-SA was synthesized using the reported method..$^{33,34}$ In a $50 \mathrm{~mL}$ flask, metronidazole ( $6 \mathrm{mmol}$ ) was dissolved in pyridine $(4 \mathrm{~mL})$. Then succinic anhydride $(9 \mathrm{mmol})$ was dissolved in anhydrous pyridine $(4 \mathrm{~mL})$ and slowly added dropwise into the above reaction mixture, within 8 minutes under stirring and ice bath condition. After completion of the reaction, the ice bath was removed. Under $\mathrm{N}_{2}$ atmosphere and avoiding of light, resulting mixture was stirred for $24 \mathrm{~h}$ at room temperature. Solvent was removed under reduced pressure. Crude product was dissolved in acetone $(25 \mathrm{~mL})$ and then diethyl ether $(50 \mathrm{~mL})$ was added, the mixture was kept overnight at room temperature. Suspension was removed by filtration. The filtrate was treated again by the procedure mentioned above. Filter cake obtained by two filtration steps was combined. The product MNZ-SA was obtained as a white crystal, $1.54 \mathrm{~g}$, yield $95 \% .{ }^{1} \mathrm{H}$ NMR $(400 \mathrm{MHz}$, DMSO- $\left.d_{6}\right) \delta: 12.22(\mathrm{~s}, 1 \mathrm{H}), 8.04(\mathrm{~s}, 1 \mathrm{H}), 4.57(\mathrm{t}, J=7.2 \mathrm{~Hz}, 2 \mathrm{H})$, $4.37(\mathrm{t}, J=7.2 \mathrm{~Hz}, 2 \mathrm{H}), 2.64(\mathrm{~s}, 3 \mathrm{H}), 2.45-2.42(\mathrm{~m}, 4 \mathrm{H}) \mathrm{ppm}$. IR (KBr): $\nu_{\max } 2534,1332,1264 \mathrm{~cm}^{-1}$.

\subsubsection{AZT-SA}

Compound AZT-SA. The details can be found in the ESI. $\dagger$ A yellow grease was obtained, $1.35 \mathrm{~g}$, yield: $92 \% .{ }^{1} \mathrm{H}$ NMR $(400$ $\left.\mathrm{MHz}, \mathrm{CDCl}_{3}\right) \delta: 12.01(\mathrm{~s}, 1 \mathrm{H}), 8.81(\mathrm{~s}, 1 \mathrm{H}), 7.22(\mathrm{~d}, J=1.6 \mathrm{~Hz}$, $1 \mathrm{H}), 5.78(\mathrm{~d}, J=1.2 \mathrm{~Hz}, 1 \mathrm{H}), 4.52(\mathrm{dd}, J=8.8,3.2 \mathrm{~Hz}, 1 \mathrm{H}), 4.29$ (dd, $J=7.6,4.8 \mathrm{~Hz}, 1 \mathrm{H}), 4.21-4.18(\mathrm{~m}, 1 \mathrm{H}), 2.69-2.66(\mathrm{~m}, 1 \mathrm{H})$, 2.51-2.48 (m, 1H), 2.01 (s, 3H), 1.48-1.45 (m, 1H) ppm. IR (KBr): $\nu_{\text {max }} 2536,1707,1289 \mathrm{~cm}^{-1}$.

\subsubsection{TC-ES-SA}

Compound 3TC-ES-SA. The details can be found in the ESI. $\dagger$ A white powder was obtained, $0.49 \mathrm{~g}$, yield: $86 \%$. ${ }^{1} \mathrm{H}$ NMR $(400$ $\left.\mathrm{MHz} \mathrm{CDCl}_{3}\right) \delta: 12.17(\mathrm{~s}, 1 \mathrm{H}), 10.10(\mathrm{~s}, 1 \mathrm{H}), 8.19$ (d, $J=7.6 \mathrm{~Hz}$, $1 \mathrm{H}), 7.22(\mathrm{~d}, J=7.2 \mathrm{~Hz}, 1 \mathrm{H}), 6.24(\mathrm{t}, J=4.0,5.2 \mathrm{~Hz}, 1 \mathrm{H}), 5.44(\mathrm{t}, J$ $=3.2 \mathrm{~Hz}, 1 \mathrm{H}), 4.50-4.40(\mathrm{~m}, 2 \mathrm{H}), 3.61-3.57(\mathrm{~m}, 1 \mathrm{H}), 3.24-3.34$ $(\mathrm{m}, 2 \mathrm{H}), 2.64(\mathrm{t}, J=8.0,6.0 \mathrm{~Hz}, 2 \mathrm{H}), 2.08(\mathrm{~s}, 3 \mathrm{H}) \mathrm{ppm}$. IR (KBr): $\nu_{\max } 2657,1738,1719 \mathrm{~cm}^{-1}$.

3.3.4 Synthesis of fluorescent labeled metronidazole MNZF. In a $50 \mathrm{~mL}$ flask, 9-aminoacridine $(3 \mathrm{mmol})$ was dissolved in anhydrous DMF (9 mL). Dimethylaminopyridine $(0.15 \mathrm{mmol})$ was added into the mixture. MNZ-SA-HAS which obtained from MNZSA (provided in the ESI $\dagger$ ) was dissolved in anhydrous DMF $(9 \mathrm{~mL})$ and slowly added dropwise into the above reaction mixture, within 15 minutes under stirring and ice bath condition. After completion of the reaction, the ice bath was removed. Under $\mathrm{N}_{2}$ atmosphere and avoiding of light, the resulting mixture was stirred at room temperature for $36 \mathrm{~h}$. Under stirring, reaction mixture was poured into the cool distillated water (the flask was kept cold with an ice bath), gradually formed deposit. After $1 \mathrm{~h}$, the suspension was filtrated with vacuum, washed with water and dried at $90^{\circ} \mathrm{C}$. Crude product was obtained as yellow powder and it was purified by column chromatography over silica gel $(30 \mathrm{~cm} \times 2 \mathrm{~cm}$, eluting with $\left.\mathrm{v}\left(\mathrm{CHCl}_{3}\right): \mathrm{v}\left(\mathrm{C}_{2} \mathrm{H}_{5} \mathrm{OH}\right)=40: 3\right)$. Solvent was removed under reduced pressure and dried in vacuum. Product was obtained as a yellow powder $7 \mathrm{mg}$, yield: $29 \% .{ }^{1} \mathrm{H}$ NMR (400 MHz, DMSO- $\left.d_{6}\right) \delta$ : $10.79(\mathrm{~s}, 1 \mathrm{H}), 8.16(\mathrm{t}, J=8.0 \mathrm{~Hz}, 8.0 \mathrm{~Hz}, 4 \mathrm{H}), 8.04(\mathrm{~s}, 1 \mathrm{H}), 7.89-7.85$ $(\mathrm{m}, 2 \mathrm{H}), 7.64-7.61(\mathrm{~m}, 2 \mathrm{H}), 4.60(\mathrm{t}, J=8.0 \mathrm{~Hz}, 8.0 \mathrm{~Hz}, 2 \mathrm{H}), 4.43(\mathrm{t}, J$ $=8.0 \mathrm{~Hz}, 4.0 \mathrm{~Hz}, 2 \mathrm{H}), 2.94(\mathrm{t}, J=8.0 \mathrm{~Hz}, 4.0 \mathrm{~Hz}, 2 \mathrm{H}), 2.68(\mathrm{t}, J=8.0$ $\mathrm{Hz}, 8.0 \mathrm{~Hz}, 2 \mathrm{H}), 2.46$ (s, 3H) ppm. IR (KBr): $\nu_{\max } 3412,1740,1263$, $757 \mathrm{~cm}^{-1}$. MS (EMS), $\mathrm{m} / z$ calcd for $\mathrm{C}_{23} \mathrm{H}_{21} \mathrm{~N}_{5} \mathrm{O}_{5}, 447.1543$, found 448.0 $[\mathrm{M}+\mathrm{H}]^{+}, 301.0[\mathrm{M}-\mathrm{MNZ}+\mathrm{Na}]^{+}, 277.0[\mathrm{M}-\mathrm{MNZ}], 195.0$ [acridine ammonia fragments $+2 \mathrm{H}]^{+}$.

\subsubsection{AZT-F}

Compound AZT-F. The details can be found in the ESI. $\dagger$ A yellow powder was obtained, $0.29 \mathrm{~g}$, yield: $27 \%$. ${ }^{1} \mathrm{H}$ NMR $(400 \mathrm{MHz}$, DMSO- $\left.d_{6}\right) \delta: 11.36(\mathrm{~s}, 1 \mathrm{H}), 10.77(\mathrm{~s}, 1 \mathrm{H}), 8.16(\mathrm{~d}, J=8.0 \mathrm{~Hz}, 4 \mathrm{H})$, $7.85(\mathrm{t}, J=8.0 \mathrm{~Hz}, 8.0 \mathrm{~Hz}, 2 \mathrm{H}), 7.62(\mathrm{t}, J=8.0 \mathrm{~Hz}, 8.0 \mathrm{~Hz}, 2 \mathrm{H}), 7.46$ $(\mathrm{s}, 1 \mathrm{H}), 6.13(\mathrm{t}, J=8.0 \mathrm{~Hz}, 4.0 \mathrm{~Hz}, 1 \mathrm{H}), 4.34-4.27(\mathrm{~m}, 2 \mathrm{H}), 4.02-3.98$ $(\mathrm{m}, 1 \mathrm{H}), 3.02(\mathrm{t}, J=8.0 \mathrm{~Hz}, 8.0 \mathrm{~Hz}, 2 \mathrm{H}), 2.83(\mathrm{dd}, J=8.0 \mathrm{~Hz}, 4.0 \mathrm{~Hz}$, $2 \mathrm{H}), 2.44(\mathrm{dd}, J=8.0 \mathrm{~Hz}, 8.0 \mathrm{~Hz}, 1 \mathrm{H}), 2.33$ (dd, $J=12.0 \mathrm{~Hz}, 8.0 \mathrm{~Hz}$, $1 \mathrm{H}), 1.80(\mathrm{~d}, J=4.0 \mathrm{~Hz}, 1 \mathrm{H}), 1.75(\mathrm{~s}, 3 \mathrm{H}) \mathrm{ppm}$. IR (KBr): $\nu_{\max } 3245$, 1708, 1272, $751 \mathrm{~cm}^{-1}$. MS (EMS), $\mathrm{m} / z$ calcd for $\mathrm{C}_{27} \mathrm{H}_{25} \mathrm{~N}_{7} \mathrm{O}_{6}$, 543.1866, found 544.1 $[\mathrm{M}+\mathrm{H}]^{+}, 301.0[\mathrm{M}-\mathrm{AZT}+\mathrm{Na}]^{+}, 277.0[\mathrm{M}-$ AZT], 195.0 [acridine ammonia fragments $+2 \mathrm{H}]^{+}$.

\subsubsection{TC-F}

Compound 3TC-ES-F. The details can be found in the ESI. $\uparrow \mathrm{A}$ yellow powder was obtained, $0.29 \mathrm{~g}$, yield: $14 \% .{ }^{1} \mathrm{H}$ NMR $(400$ $\mathrm{MHz}, \mathrm{CDCl}_{3}$ ) $\delta: 8.34(\mathrm{dd}, J=8.0 \mathrm{~Hz}, 8.0 \mathrm{~Hz}, 2 \mathrm{H}), 8.13(\mathrm{~d}, J=8.0$ $\mathrm{Hz}, 1 \mathrm{H}), 7.82(\mathrm{~s}, 1 \mathrm{H}), 7.74(\mathrm{dd}, J=8.0 \mathrm{~Hz}, 8.0 \mathrm{~Hz}, 3 \mathrm{H}), 7.57$ (dd, $J$ $=16.0 \mathrm{~Hz}, 8.0 \mathrm{~Hz}, 2 \mathrm{H}), 7.20(\mathrm{~s}, 1 \mathrm{H}), 6.49(\mathrm{~d}, J=4.0 \mathrm{~Hz}, 1 \mathrm{H})$, $6.32-6.29(\mathrm{~m}, 1 \mathrm{H}), 5.40(\mathrm{dd}, J=8.0 \mathrm{~Hz}, 4.0 \mathrm{~Hz}, 1 \mathrm{H}), 4.63$ (ddd, $J$ $=12.0 \mathrm{~Hz}, 8.0 \mathrm{~Hz}, 4.0 \mathrm{~Hz}, 2 \mathrm{H}), 3.66(\mathrm{dt}, J=8.0 \mathrm{~Hz}, 8.0 \mathrm{~Hz}, 8.0$ $\mathrm{Hz}, 1 \mathrm{H}), 3.33(\mathrm{dd}, J=12.0 \mathrm{~Hz}, 4.0 \mathrm{~Hz}, 1 \mathrm{H}), 3.12(\mathrm{t}, J=8.0 \mathrm{~Hz}, 4.0$ $\mathrm{Hz}, 2 \mathrm{H}), 2.32(\mathrm{t}, J=8.0 \mathrm{~Hz}, 4.0 \mathrm{~Hz}, 2 \mathrm{H}), 2.15$ (s, 3H) ppm. IR (KBr): $\nu_{\max } 3223,1733,1694,1221,757 \mathrm{~cm}^{-1}$. MS (EMS), $\mathrm{m} / z$ calcd for $\mathrm{C}_{27} \mathrm{H}_{25} \mathrm{~N}_{5} \mathrm{O}_{6} \mathrm{~S}$, found $543.2\left[\mathrm{M}-\mathrm{CH}_{3} \mathrm{CO}+\mathrm{K}\right]^{+}, 195.1$ [acridine ammonia fragments $+2 \mathrm{H}]^{+}$and $272[\mathrm{M}-3 \mathrm{TC}-\mathrm{ES}+$ $5 \mathrm{H}]^{+}$fragment ion peak.

\subsection{Competitive binding assay}

Competitive binding assay of MNZ-F was discussed in this manuscript as an example, and for AZT-F can be found in the ESI. $\dagger$ Molecularly imprinted polymers synthesized according to the procedure reported in our previous work. ${ }^{30,35}$ MIPs particles of MNZ (20 mg) were mixed with $0.018 \mathrm{mM}$ of MNZ-F and the MNZ (final concentration $0-0.36 \mathrm{mM}$ ) in the chloroform solvent up to a final volume of $4 \mathrm{~mL}$. The mixture was incubated for $12 \mathrm{~h}$ at room temperature in polypropylene tubes on a shaking table. After shaking, the solution was centrifugated and filtrated. Finally, the filtrate was measured by fluorescence spectrometer. 


\section{Conclusions}

Three different drug molecules were labeled with a fluorophore 9-aminoacridine. The UV-vis absorption spectra and the fluorescent properties of the fluorophore-labeled drug molecules were studied. No ground state interaction was observed for the drug labeled with fluorophores. AZT-F exhibited higher fluorescence intensity in $\mathrm{H}_{2} \mathrm{O}$, 9-AA and MNZ-F showed higher fluorescence intensity in methanol. The binding assay using metronidazole, zidovudine, lamivudine and molecularly imprinted polymers of these three drugs was studied. The results showed that a good linear relationship was established between the concentration of the drug and the relative fluorescence intensity. Our results are useful for the further establishment of immunofluorescence analysis which can be applied in the analysis of biological and medical sample in the future.

\section{Conflicts of interest}

There are no conflicts to declare.

\section{Acknowledgements}

This work was supported by the National Natural Science Foundation of China (Grants No. 21462043, 21365020 and 21565025) and the State Key Laboratory of Fine Chemicals (KF 1617).

\section{References}

1 M. S. T. Gonçalves, Chem. Rev., 2009, 109, 190-212.

2 L. Fu, X. F. Liu, Q. X. Zhou, J. X. Zhang, J. Y. Dong and J. Y. Wang, J. Lumin., 2014, 149, 208-214.

3 T. A. Goolsby, B. Jakeman and R. P. Gaynes, Int. J. Antimicrob. Agents, 2018, 51, 319-325.

4 H. Liu, F. Gambino, C. Algenio, C. Bouchard, L. Qiao, P. Bu and S. Zhao, Biochem. Biophys. Res. Commun., 2018, 499, 177-181.

5 N. Shahabadi and N. H. P. Moghadam, J. Lumin., 2013, 134, 629-634.

6 R. M. Gibson, G. Nickel, M. Crawford, F. Kyeyune, C. Venner, I. Nankya, E. Nabulime, E. Ndashimye, A. F. Y. Poon, R. A. Salata, C. Kityo, P. Mugyenyi, M. E. Quiñones-Mateu and E. J. Arts, Infect. Dis. Poverty, 2017, 6, 163.

7 A. K. Jena, A. K. Nayak, A. De, D. Mitra and A. Samanta, Future Journal of Pharmaceutical Sciences, 2018, 4, 71-79.

8 F. Y. Ge, X. L. Yan, H. Y. Fan, X. L. Zhou and L. G. Chen, Chin. J. Anal. Chem., 2005, 33, 1199-1204.

9 P. Garriga, D. Garcia-Quintana and J. Manyosa, Biochem. Biophys. Res. Commun., 1992, 185, 110-115.

10 C. Manivannan and R. Renganathan, J. Lumin., 2011, 131, 2365-2371.

11 G. Haydar, M. Imerhasan, K. A. Eshbakova and A. E. Kurbanbaeva, J. Pharm. Biol. Sci., 2016, 4, 41-45.
12 H. R. Zhuang, S. C. Feng and M. Ping, Phys. Test. Chem. Anal., Part B, 2001, 37, 143-146.

13 B. E. Song, M. H. Li and M. Imerhasan, Chin. J. Org. Chem., 2018, 38, 594-611.

14 X. Chen and Y. W. Wu, Org. Biomol. Chem., 2016, 14, 54175439.

15 A. Jha, C. Mukherjee, A. K. Prasad, V. S. Parmar, M. Vadaparti, U. Das, E. De Clercq, J. Balzarini, J. P. Stables, A. Shrivastav, R. K. Sharma and J. R. Dimmock, Bioorg. Med. Chem. Lett., 2010, 20, 15101515.

16 A. Lundgren, Y. Hed, K. Öberg, A. Sellborn, H. Fink, P. Löwenhielm, J. Kelly, M. Malkoch and M. Berglin, Angew. Chem., Int. Ed., 2011, 50, 3450-3453.

17 T. E. Ballard, J. J. Richards, A. L. Wolfe and C. Melander, Chem.-Eur. J., 2008, 14, 10745-10761.

18 Y. L. Kam, H. K. Rhee, H. J. Kim, S. K. Back, H. S. Na and H. Y. P. Choo, Bioorg. Med. Chem. Lett., 2010, 18, 2327-2336.

19 Y. Y. Huang, T. Meng, G. W. Qu and C. Zhang, J. China Pharm. Univ., 2011, 42, 294-298.

20 L. Mattsson, J. Xu, C. Preininger, B. T. S. Bui and K. Haupt, Talanta, 2018, 181, 190-196.

21 X. A. Ton, V. Acha, P. Bonomi, B. T. S. Bui and K. Haupt, Biosens. Bioelectron., 2015, 64, 359-366.

22 K. Haupt, A. G. Mayes and K. Mosbach, Anal. Chem., 1998, 70, 3936-3939.

23 I. Chianella, A. Guerreiro, E. Moczko, J. S. Caygill, E. V. Piletska, I. M. Perez De Vargas Sansalvador, M. J. Whitcombe and S. A. Piletsky, Anal. Chem., 2013, 85, 8462-8468.

24 T. Zhang, J. Liu and J. P. Wang, Anal. Methods, 2018, 10, 5025-5031.

25 M. Homocianu, A. Airinei and D. O. Dorohoi, J. Adv. Res. Phys., 2011, 2, 1-9.

26 J. Nakanishi, T. Nakajima, M. Sato, T. Ozawa, K. Tohda and Y. Umezawa, Anal. Chem., 2001, 73, 2920-2928.

27 A. Kellmann, J. Chem. Phys., 1977, 81, 1195-1198.

28 J. S. Seixas de Melo, R. S. Becker and A. L. Macanita, J. Chem. Phys., 1994, 98, 6054-6058.

29 S. Uchiyama, K. Takehira, T. Yoshihara, S. Tobita and T. Ohwada, Org. Lett., 2006, 8, 5869-5872.

30 T. Muhammad, A. Kadier, H. Mamat and N. Abudukeyoumu, Chin. J. Anal. Chem., 2011, 39, 1841-1845.

31 J. Sebestík, J. Hlavácek and I. Stibor, Curr. Protein Pept. Sci., 2007, 8, 471-483.

32 Z. K. Chen, W. Huang, L. H. Wang, E. T. Kang, B. J. Chen, C. S. Lee and S. T. Lee, Macromolecules, 2012, 33, 9015-9025.

33 C. C. Lu, Z.-S. Quan, J. C. Sur, S.-H. Kim, C. H. Lee and K. Y. Chai, New J. Chem., 2010, 34, 2040-2046.

34 D. G. Carole, S. Kamal, B. Gérard, D. Florence and J.-P. Galy, Eur. J. Med. Chem., 2007, 42, 1277-1284.

35 Z. Nur, T. Muhammad and Z. Muhammad, Chin. J. Anal. Lab., 2013, 32, 6-10. 